\title{
ANALISIS KITAB AL MUSTASHFA KARYA AL GHAZALI
}

\author{
Solikhul Hadi \\ Institut Agama Islam Negeri Kudus
}

solikhu1623@gmail.com

\begin{abstract}
At the end of the second and third centuries, Imam Muhammad bin Idris Asy-syafi'i (150-204 H) founder of the Shafi'i school, appeared in concocting, systematizing and recording the usul fiqh. He was the first to record the science of ushul fiqh with his book entitled Al-Risalah. The ushul fiqh analysts say that during the fourth time the imam of the school, ushul fiqh finds its perfect form, so that later generations tend to choose and use the method according to the case faced in their own time. In particular the book of Al Mustashfa is interesting to peel, because the book is composed not only by using Shafi'iyyah method but also other approaches such as philosophy and tasawuf. The results of the analysis show the advantages that exist in this book are: First, the authors consistent in applying the method nadlariyat amaliyat a Shafi'iyah method that uses the standard of objectivity and empiricity. Secondly, the author is no longer bound (taqlid) with his school, even there is a difference of opinion with the imam of his school. For example, the author does not agree with the use of mafhum as stated by Imam Shafi'i. The authors' independence attitudes are in accordance with the Mutakallimin Method which constantly searches for objective truth and avoids taqlid. And third, the systematic discussion is quite interesting and facilitate the reader in analyzing ushul figh. The lack of writing this book is: First, the layout of the less elegant layout, and requires the attention of the competent parties including printing. Secondly, coverage in the discussion of ushul fiqh has not been comprehensively. For example, the problem of urf and sad al dhari'ah has not been discussed in the book.
\end{abstract}

Keywords; Analysis, Book of Al Mustashfa 


\section{A. Pendahuluan}

Pada penghujung abad kedua dan awal abad ketiga, Imam Muhammad bin Idris Asy-syafi'i (150-204 H) pendiri mazhab Syafi'i, tampil dalam meramu, mensistematisasi dan membukukan ushul fiqh. Pada masa ini ditandai dengan pesatnya perkembangan ilmu pengetahunan keislaman dengan ditandai didirikannya "Baitul-Hikmah", yaitu perpustakaan terbesar di kota Baghdad pada masa itu (Effendi, 2009: 19).

Dengan berkembang pesatnya ilmu pengetahuan, Imam Syafi'i yang datang kemudian, banyak mengetahui tentang metode istinbath para mujtahid sebelumnya, sehingga beliau mengetahui di mana keunggulan dan di mana kelemahannya. Beliau merumuskan ushul fiqh untuk mewujudkan metode istinbath yang jelas dan dapat dipedomani oleh peminat hukum Islam, untuk mengembangkan mazhab fiqhnya, serta untuk mengukur kebenaran hasil ijtihad di masa sebelumnya. Beliau merupakan orang pertama yang membukukan ilmu ushul fiqh. Kitabnya yang berjudul AlRisalah menjadi bukti bahwa beliau telah membukukan ilmu Ushul fiqh.

Pada abad ketiga, banyak bermunculan karya-karya ilmiah dalam bidang ini. Salah satunya buku Al-Nasikh wa Al-Mansukh oleh Ahmad bin Hanbal (164-241H) pendiri mazhab Hanbali. Pertengahan abad keempat ditandai dengan kemunduran dalam kegiatan ijtihad di bidang fiqh, dengan pengertian tidak ada lagi orang yang mengkhususkan diri membentuk mazhab baru. Namun kegiatan kajian dalam bidang ushul fiqh berkembang pesat. Para ahli analisis ushul fiqh mengatakan bahwa pada masa keempat imam mazhab tersebut, ushul fiqh menemukan bentuknya yang sempurna, sehingga generasi-generasi sesudahnya cenderung memilih dan menggunakan metode yang sesuai dengan kasus yang dihadapi pada zaman masing-masing (Umam, 2008: 28).

Aliran-aliran dalam karya ushul fiqh: Pertama, Aliran Mutakalimin (Syafi'iyah). Aliran ini berpegang pada analisisanalisis kebahasaan ( linguistic ). Dalam membangun teori, aliran ini menetapkan kaidah-kaidah dengan alasan yang kuat, baik dari naqli (Al-Qur'an dan atau Sunnah) maupun dari aqli (akal pikiran), tanpa dipengaruhi oleh masalah-masalah furu' dari berbagai mazhab, sehingga teori tersebut adakalanya sesuai dengan furu' dan adakalanya tidak ( Haroen, 1997: 12).

Yudisia, Vol. 9, No. 1, Jan-Jun 2018 
Ketidakterikatan dengan masalah-masalah furu' yang telah ada dari suatu mazhab, menjadikan pembahasan mereka lebih bersifat teoritis. Para ulama Mutakallimin ini menciptakan kaidahkaidah ushul atas tuntutan ilmiah dan melakukan langkah-langkah secara deduktif (Jumantoro dan Amin, 2005: 345).

Di antara kitab-kitab yang disusun dengan menggunakan metode ini adalah;

a). Kitab Al Mu'tamad (المعتمد)

Pengarang : Abu al Husain Muhammad bin Ali al Bashri, dari golongan Mu'tazilah. Wafat tahun $413 \mathrm{H}$.

b). Kitab Al Burhan (البر هان)

Pengarang : Imam al Haramain, dari mahab Syafi'i. Wafat tahun $487 \mathrm{H}$

c). Kitab Al Mustashfa (المستصفى)

Pengarang : Imam al Ghazali, dari mazhab Syafi'i. wafat tahun $505 \mathrm{H}$

Kedua, Aliran Fuqaha (Hanafiyah). Aliran ini dalam membangun teori ushul fiqhnya banyak dipengaruhi oleh masalah furu' dalam mazhab mereka. Penetapan kaidah-kaidah ushul berdasarkan hukum-hukum furu' (hukum yang sudah berkembang dimasyarakat) (Jumantoro dan Amin, 2005: 345).

Mereka tidak membangun suatu teori kecuali setelah melakukan analisis terhadap masalah-masalah furu' yang ada dalam mereka. Dalam menetapkan teori tersebut, apabila terdapat pertentangan antara kaidah yang ada dengan hukum furu', maka kaidah tersebut diubah dan disesuaikan dengan hukum furu' tersebut ( Haroen, 1997: 13).

Di antara kitab ushul fiqh dengan metode ini adalah:

a). Kitab al Ushul (الاصول)

Pengarang: Abu al Hasan al Karkhi, dari mazhab Hanafi. Wafat tahun $370 \mathrm{H}$.

b). Kitab Ta'sis al Nadlar (تأسبس النظر)

Pengarang: Al Dabusi, dari mazhab Hanafi. Wafat tahun 430 $\mathrm{H}$.

c). Kitab Ushul al Bazdawi (اصول البزدوي)

Pengarang: Al Bazdawi, dari mazhab Hanafi. Wafat 483 H.

d). Kitab Al Mabsuth (المبسوط)

Pengarang: Al Sarakhsi, dari mazhab Hanafi. 
Dan ketiga, Aliran Gabungan, aliran ini menggabungkan kedua metode yang dipakai dalam menyusun ushul fiqih oleh aliran Syafi'iyah dan aliran Hanafiyyah. Aliran ini mengemukakan bahwa alasan-alasan yang kuat dan juga memperhatikan penyesuaiannya dengan hukum-hukum furu' yang telah ada (Jumantoro dan Amin, 2005: 347).

Di antara kitab-kitab ushul figh yang ditulis dengan menggunakan metode terpadu ini adalah;

a) Kitab Badi' al Nidlam (بديع النظام)

Pengarang: Ahmad bin Ali As Sa'ati al Baghdadi. Wafat tahun $694 \mathrm{H}$.

b) Kitab Tanqih al Ushul (تنقيح الاصول)

Pengarang : Abdullah bin Mas'ud al Bukhari. Wafat tahun 747

c) Kitab Al Taudhih (التوضيح)

Pengarang : Abdullah bin Mas'ud al Bukhari. Wafat tahun $747 \mathrm{H}$.

c) Kitab Jam'u al Jawami' (جمع الجوامع)

Pengarang : Tajuddin Abdul Wahab As Subki. Wafat tahun $771 \mathrm{H}$

d) Kitab Al Tahrir (التحرير)

Pengarang : Kamaluddin Ibn al Hammam. Wafat $861 \mathrm{H}$.

e) Kitab Mussalm al Tsubut (مسلم الثبوت)

Pengarang: Muhibullah bin Abdul Syaku al Hindi (Zahrah, tt: 11-24).

Secara khusus kitab Al Mustashfa menarik untuk dikupas, karena kitab tersebut disusun bukan hanya dengan menggunakan metode Syafi'iyyah namun juga adanya pendekatan-pendekatan yang lain seperti filsafat dan tasawuf.

Diharapkan pembaca dapat menikmati dan menganalisa penjelajahan keilmuan Hujjatul Islam Imam al Ghazali dalam menyusun kitab Al Mustashfa ini.

\section{B. Biografi Penulis}

Nama lengkap penulis adalah Abu Hamid Muhammad bin Muhammad bin Muhammad bin Muhammad Al Ghazali. Dia lahir di Thus, wilayah Khurasan, pada tahun $450 \mathrm{H}$. Ayahandanya adalah seoarang shaleh yang bekerja sebagai penenun sutera, dan dikaruniai dua orang anak yaitu, penulis (Imam Ghazali) dan seorang saudaranya yang benama Abul Futuh Ahmad bin 
Muhammad bin Muhammad bin Muhammad bin Muhammad Al Ghazali, dan lebih tekenal dengan nama Majduddin (wafat tahun $520 \mathrm{H})$.

Semenjak kecil penulis terkenal sebagai ahli fiqh di daerahnya yaitu Thus, wilayah Khurasan. Kemudian dia melakukan perjalanan ke Jurjan dan berguru kepada Abu Nashar Al Isma'ili, dan kemudian melanjutkan perjalanan ke Naisabur dan berguru kepada ulama besar di bidang fiqh, Imam Al Haramain Abu Al Ma'ali Al Juwaini. Selain di bidang fiqh, dia juga belajar manthiq dan ilmu kalam. Sepeninggal Imam Al Haramain, dia menuju ke Askar dan bertemu dengan penguasa Nizam al Muluk, yang kemudian mengamanatkan kepada penulis untuk mengajar di Madrasah Nizamiyah di Baghdad. Dia mengajar di Madrasah itu pada tahun $484 \mathrm{H}$, dan mulai saat itu penulis mulai tampak bersinar keilmuannya pada abad ke-5 tersebut.

Penulis secara diam-diam berkeinginan untuk pergi ke Syam (Siria) dan kemudian ke Makkah, dengan pertimbangan ingin menekuni dunia ilmu dan mencari ketenangan hati tanpa adanya keterkaitannya dengan dunia politik seperti yang melingkupinya pada saat di Baghdad. Keinginannya betul-betul terwujud, dengan bekal yang cukup sederhana akhirnya dia meninggalkan Baghdad dan menuju Syam. Di sana dia melakukan uzlah, khalwah, riyadhah, dan mujahadah. Setiap saat kesibukannya di isi dengan membersihkan jiwa, akhlak dan hati dengan banyak melakukan i'tikaf di masjid Damaskus. Keinginan berikutnya yaitu hendak ke Makkah dan melakukan ziarah ke makam Rasulullah saw juga terlaksana. Kehidupannya kini jauh berubah, dengan segala kesederhanaan baik pakaian, makanan dan minuman menjadi yang sudah akhlak kesehariannya. Pada saat kulminasi itulah dia mengarang sebuah kitab tasawuf monumental yaitu Ihya Ulum al Din. Dengan kitab itu pula dia akhirnya kembali ke Baghdad.

Perjalanan selanjutnya, dia menuju ke Khurasan dan bertemu dengan putera Nidzam Al Muluk yang memintanya untuk mengajar kembali di Madrasah Nizamiyah di Naisabur. Tawaran penguasa itu ternyata ditolak oleh Sang Imam dengan alasan ingin menekuni ibadah. Penolakannya itu membuat Sang Penguasa memintanya lagi untuk kedua kalinya, dan mengatakan tidak layak bagi tuan untuk menolak mengajarkan ilmu bagi umat Islam. Akhirnya, Al Ghazali dapat menerim alasan itu, dan dia kembali mengajar di Madrasah itu dalam waktu sebentar. Dengan bermusyawarah 
bersama para ulama maka akhirnya dia benar-benar mencurahkan ilmunya di Naisabur pada tahun $599 \mathrm{H}$, dengan mengalahkan keinginannya untuk uzlah. Setelah itu dia pindah lagi ke Thus untuk mengajar fiqh, tashawuf dan lain-lain hingga akhir hayatnya pada tahun $505 \mathrm{H}$. (Al Ghazali, tt: 7-23).

Kitab-kitab yang telah ditulis oleh Imam ghazali cukup banyak, di antaranya; Ihya 'Ulum al Din kitab, Tahafut al Falasifah, Al Iqtishad fi al I'tiqad, Al Munqiz min al Dhalal, Jauhar al Qur'an, Mizan al 'Amal, Al Maqshid al Asna fi ma'ani al Asma' al Husna, Faisahal al Tafriqah baina al Islam wa al Zindiq, Al Qisthas al mustaqim.

\section{Sistematika Penulisan}

Penulis kitab Al Mustashfa ini memiliki spesifikasi dalam penulisan sistematika kitab ushul fiqh yang tidak dimiliki oleh penulis yang lain. Keistimewaan tersebut terletak pada klasifikasi ushul fiqh menjadi empat kelompok dasar, yang kemudian masingmasing kelompok dasar tersebut memiliki cabang. Klasifikasi tersebut dimaksudkan untuk mempermudah kajian bagi para pembaca, dan sekaligus menempatkan substansi ushul fiqh pada posisi yang benar.

Rincian klasifikasi dan sistematika tersebut adalah sebagai berikut:

1. Hasil / buah (Tsamrah), yang dimaksudkan dengan hasil / buah adalah hukum, terdiri dari:

a) Hakikat hukum, meliputi; definisi hukum dan pandangan Mu'tazilah tentang baik dan buruk.

b). Pembagian hukum, meliputi; wajib, mandub, mahdzur, makruh dan mubah.

c). Rukun-rukun hukum, meliputi; syarat-syarat taklif.

d). Hal-hal yang menjadikan hukum menjadi jelas, meliputi; - Asbab

- Sah, batal dan fasad

- Ada', qadla' dan i'adah

- Azimah dan rukhshah

Yang membuahkan hasil (Mutsmir), meliputi;

a). Al Qur'an, meliputi; masalah Basmalah, hakikat dan majaz, muhkam dan mutasyabih, dan nasakh.

b). As Sunnah, meliputi; ungkapan sahabat, mutawatir, hadits yang wajib dan tidak wajib diterima 
kebenarannya, hadits ahad, hadits sahih, dan periwayatan hadits.

c). Al Ijma', meliputi; kehujjahan ijma', rukun ijma', dan hukum ijma'

d). Dalil Akal dan istishab

Pada klasifikasi bab ini, penulis menyebutkan beberapa term dalam ushul fiqh yang tidak tepat untuk dijadikan sebagai sumber dalil (اصول الادلة), yaitu;
a). Syar'u man qablana
b). Qaul al Shahabi
c). Istihsan
d). Istishlah

2. Metode untuk menghasilkan hukum (Kaifiyat istitsmar al ahkam), meliputi;

a). Istidlal dengan menggunakan redaksional (shighat) nash, meliputi; Dasar-dasar kebahasaan, nama-nama lughawiah, nama-nama 'urfiyah, nama-nama syar'iyah, ungkapan yang berfaidah, cara mengetahui isi ungkapan, mujmal dan mubayyan, 'am dan khash, amar dan nahi, istisna', syarat dan taqyid.

b). Istidlal dengan menggunakan isyarat nash, meliputi; manthuq dan mafhum.

c). Istidlal dengan menggunakan dasar lafadz, meliputi; dasarketetapan qiyas, cara menetapkan illat, qiyas syabah, dan rukun qiyas.

3. Ketentuan bagi orang yang hendak menghasilkan hukum (hukmu al mustatsmir), meliputi:

a). Ijtihad, meliputi ijtihad pada zaman Rasul, kebenaran ijtihad, dan pembatalan ijtihad.

b). Taqlid dan istifta', meliputi; definisi taqlid dan kewajiban orang awam bertaqlid dan istifta'.

c). Tarjih, meliputi; penyusunan dalil secara tertib, ta'arudl, dan tarjih.

\section{Pembahasan}

Pertama; Menurut penulis, hukum adalah ungkapan yang merupakan implementasi dari khithab Syari' ( Allah dan RasulNya ) yang berkaitan dengan perbuatan orang-orang mukallaf. Ketika khithab ini bukan bersumberkan dari Syari' maka tidak dapat dikatakan sebagai hukum. Oleh karena itu, akal tidak dapat 
memberikan legalitas baik dan buruk, serta menetapkan hukum bagi perbuatan mukallaf sebelum ada ketentuan dari Syari'.

Menurut pendapat golongan Mu'tazilah perbuatan mukallaf dapat dibedakan menjadi dua, yaitu baik dan buruk. Di antara kedua hal tersebut ada yang dapat ditentukan secara dharuri oleh akal, misalnya menyelamatkan orang yang tenggelam dan celaka adalah baik, sedangkan yang buruk misalnya kufur dan berbohong dengan tanpa tujuan yang baik. Perbuatan mukallaf yang lain dapat diketahui dengan nadhar (penalaran), seperti berbohong untuk hal kebaikan adalah buruk. Dan di antara perbuatan mukallaf yang lain hanya dapat ditemukan melalui sama' (wahyu), seperti ibadah shalat adalah baik.

Menurut pendapat penulis, yang berbeda dengan pandangan golongan Mu'tazilah, ia menyatakan bahwa untuk menentukan masalah baik dan buruk tidak bisa dengan mudah hanya menggunakan akal, tetapi harus melihat dan memahami hakikat baik dan buruk itu (Al Ghazali, tt: 45).

Kedua; Penulis membahas masalah nasakh secara detail, termasuk rukun dan syarat-syaratnya. Nasakh memiliki 4 rukun dan 4 syarat sekaligus. Empat rukun untuk naskh tersebut adaalah; nasakh (perombakan hukum), naskih (yang merombak), mansukh (hukum yang dirombak), dan mansukh 'anhu (hukum yang ditetapkan dan digunakan untuk merombak). Hakikat nasakh adalah merombak hukum, dan oleh karenanya yang berhak melakukan nasakh, atau yang disebut dengan term nasikh adalah Allah swt.

Adapun syarat nasakh yang empat itu adalah;

(1). Hukum yang dirombak (mansukh) haruslah hukum syar'i, bukan hukum aqli.

(2). Perombakan hukum haruslah berdasarkan pada khithab (ketetapan syari'at).

(3). Hukum yang dirombak haruslah berupa hukum yang tidak muqayyad bi al waqti (dibatasi oleh waktu), seperti firman Allah swt; kemudian sempurnakanlah puasa sampai malam hari ... (QS. Al Baqarah; 187).

(4). Hukum yang merombak haruslah datang belakangan.

Berangkat dari prinsip-prinsip nasakh di atas, maka persoalan menjadi berkembang dalam beberapa kasus berikut ini;

Yudisia, Vol. 9, No. 1, Jan-Jun 2018 
a. Setiap hukum syar'i dapat menerima nasakh. Pendapat ini berbeda dari pendapat golongan Mu'tazilah yang menyatakan hal-hal yang secara otomatis bersifat baik atau buruk maka tidak dapat menerima nasakh. Mereka mencontohkan, ma'rifat kepada Allah, sifat adil,dan bersyukur kepada Allah, ketetapan wajibnya sudah jelas dan tidak dapat dinasakh. Demikian pula, kufur, dlalim, dan berbohong memiliki ketetapan haram yang tidak bisa dinasakh.

b. Ayat-ayat ahkam dapat dinasakh tulisannya saja tanpa nasakh hukumnya, atau nasakh hukumnya saja tanpa tulisannya, atau nasakh pada hukum dan tulisannya sekaligus.

c. Ayat Al Qur'an dapat dinasakh oleh As Sunnah, dan sebaliknya As Sunnah dapat dinasakh oleh ayat Al Qur'an karena keduanya adalah sama-sama wahyu dari Allah swt.

d. Tidak terjadi nasakh pada ijma'. Nasakh tidak terjadi setelah berakhirnya wahyu. Sedangkan As Sunnah mutawatir dapat dinasakh dengan As Sunnah mutawatir pula. Demikian pula, As Sunnah ahad dapat dinasakh dengan As Sunnah ahad juga. Adapun persoalan As Sunnah mutawatir yang dinasakh dengan As Sunnah ahad menjadi kontrofersial di kalangan ulama.

e. Nash yang sudah qath'i serta mutawatir tidak dapat dinasakh oleh qiyas baik qiyas jaliy maupun qiyas khafiy, demikian menurut pendapat jumhur ulama.

f. Suatu hukum tidak dapat dinasakh oleh pendapat shahabat, kecuali jikalau shahabat tersebut menyatakan saya mendengar sendiri dari Rasulullah telah merombak hukum tersebut (Al Ghazali, tt: 90)

Ketika penulis menyatakan akal dan istishab sebagai sumber dalil, maka dia berargumentasi bahwa memang sesngguhnya akal tidak dapat serta merta menjangkau hukum-hukum yang sudah dinash. Namun, akal dapat menentukan baraat al dzimmat (bebas tanggungan) bagi manusia atas segala beban kewajiban sebelum diutusnya Rasul yang dikuatkan dengan mu'jizat. Demikian juga beban hukum dianggap tidak ada bagi manusia selama tidak ada nash yang menentukannya. Jika Nabi menyatakan kewajiban shalat lima waktu bagi manusia, maka akal akan menentukan dengan 
istsihabnya bahwa shalat yang keenam tidak ada, karena berdasarkan ketenuan yang ada (Al Ghazali, tt: 159).

Dalam kitab yang ditulis oleh penulis ini terdapat hal yang menarik, di mana dia menyatakan ada 4 term ushul fiqh yang sebenarnya bukan termasuk sumber-sumber dalil untuk dijadikan istidlal, walaupun selama ini terlanjur banyak yang memasukkan keempat hal tersebut sebagai sumber dalil.

Dan berikut ini adalah 4 term dalam ushul figh itu berikut argumentasi yang dibangun oleh penulis untuk menafikannya sebagai sumber dalil;

(1). Syar'u man qablana (syari'at orang-orang sebelum kita)

Sebagian orang mengatakan bahwa Nabi saw. mengikuti syari'at nabi sebelumnya, sedangkan sebagian yang lain menyatakan tidak. Ada yang menyebutkan Nabi Muhammad saw. mengikuti syari'at Nabi Ibrahim, atau Nabi Musa, dan ada pula yang menyatakan mengikuti Nabi Isa. Dan secara logika memang hal ini bisa saja terjadi, namun dalam kenyataannya tidak demikian.

Dalam hal ini penulis menegaskan bahwa Nabi Muhammad saw. tidaklah mengikuti syari'at nabi sebelumnya. Ada empat alasan yang mendasarinya;

a). Ketika Rasul mengutus Mu'adz bin Jabal ke Yaman, kemudian beliau bertanya kepada Mu'adz; dengan apa engkau menghukumi persoalan? Kemudian Mu'adz menjawab dengan Al Qur'an, As Sunnah dan Ijtihad, tanpa menyebutkan kitab Taurat, Injil dan Syar'u man qabana, maka Rasul membenarkannya.

b). Seandainya Rasulullah saw. diharuskan menggunakan syaru man qablana maka pastilah beliau akan senantiasa menggunakannya dalam menghadapi persoalan tanpa menunggu turunnya wahyu.

c). Seandainya memang syar'u man qablana masih digunakan maka pastilah menjadi wajib mempelajari, mendalami dan mentransformasi, termasuk bagi generasi shahabat dan sesudahnya.

d). Sudah menjadi ijma' di kalangan umat Islam bahwa Syari'at Nabi Muhammad adalah syari'at yang merombak ajaran sebelumnya, dan secara keseluruhan adalah berasal dari syari'an Rasul saw.

(2). Qaul al shahaby (pendapat shahabat)

Yudisia, Vol. 9, No. 1, Jan-Jun 2018 
Posisi pendapat shahabat apakah menjadi sumber dalil atau tidak masih menjadi khilafiyah di kalangan ulama. Ada di antara ulama yang mengatakan pendapat shahabat menjadi sumber dalil secara mutlak. Sebagian ulama yang lain berpendapat hanya pendapat Sahahabat Abu Bakar dan Umar yang dapat dijadikan sebagai sumber dalil, berdasarkan sabda Nabi saw;

اقتدو ا بالذين من بعدي

Sedangkan ulama yang lainnya berpandangan bahwa pendapat sahabat yang dapat dijadikan sebagai sumber dalil adalah pendapat Al Khulafa' al Rasyidun.

Menurut pendapat penulis, semua pendapat di atas adalah salah. Alasannya karena yang dapat dijadkan sebagai sumber dalil hanyalah yang berasal dari orang yang bersifat ma'shum, sedangkan para shahabat tidak bersifat ma'shum.

(3). Istihsan

Ada tiga pengertian atau makna bagi term istihsan, dan kesemuanya itu disangkal oleh penulis, yaitu;

a). Istihsan adalah sesuatu yang dianggap baik oleh mujtahid berdasarkan logika. Menurut penulis istihsan yang demikian ini adalah batal karena persoalan hukum harusnya dikembalikan pada nash yang bersifat wahyu, bukan akal yang berpotensi mengikuti hawa nafsu.

b). Istihsan adalah suatu dalil yang sulit untuk diungkapkan secara redaksional oleh para mujtahid. Menurut penulis istihsan yang demikian ini juga batal, karena definisi yang tidak jelas akan mengakibatkan in put dan out put hukum menjadi rancu.

c). Istihsan adalah berpindah dari menggunakan dalil yang semisal pada kasus yang serupa disebabkan adanya hal/dalil tertentu. Contoh istihsan ini adalah jika seseorang berkata

$$
\text { مالي صدقة او لله علي ان أنصدق بمالي }
$$

Berdasarkan qiyas maka sesungguhnya dia wajib bersedekah dengan segala hal yang pantas dianggap sebagai harta. Namun, menurut Abu Hanifah yang dimaksud harta di sini adalah harta zakat, bukan yang lain, hal ini karena adanya ketentuan dari Al Qur'an;

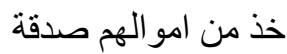


Menurut penulis, cara istidlal yang demikian ini dibenarkan, namun yang tidak tepat adalah istilah yang digunakaannya itu dengan sebutan istihsan.

(4). Istishlah

Istishlah adalah penetapan hukum berdasarkan kemaslahatan. Kemaslahatan ada tiga macam;

a). Maslahat yang didukung oleh dalil syar'i.

Kemaslahatan ini dapat dijadikan hujjah, karena sesungguhnya metode ini adalah metode qiyas. Contoh, menetapkan keharaman setiap hal yang memabukkan baik makanan maupun minuman yang diqiyaskan dengan khamr.

b). Maslahat yang tidak didukung oleh dalil syar'i, bahkan bertentangan dengan dalil itu. Contoh, ketetapan kafarat berpuasa dua bulan berturut-turut bagi orang kaya yang membatalkan puasa dengan jima', dengan pertimbangan akan terlalu ringan jika ditetapkan baginya sanksi memerdekakan budak. Ketetapan ini jelas batalnya karena bertentangan dengan nash.

c). Maslahat yang tidak dilarang maupun diperintahkan oleh nash.

Kemaslahatan ini mencakup tiga tngkatan yaitu; dharury (pokok), hajiy (seconder), dan tahsiny (pelengkap).

Penulis mnyebutkan persyaratan-persyaratan bagi maslahat mursalat agar dapat diterima sebagai suatu metode istidlal, di antaranya;

1). Maslahat harus sesuai dengan maqashid al syari'ah (tujuan syariah), yaitu; Menjaga agama, jiwa, akal, keturunan dan harta.

2). Maslahat harus benar-benar sangat mendesak (darurat)

3). Maslahat harus berdasarkan kepastian (Qath'i).

4). Masalahat bersifat general, bukan spesial.

Penulis berpandangan, pada prinsipnya maslahat mursalat dapat digunakan sebagai metode istidlal, namun bukan menempatannya sebagai ushul al adillah (dasar-dasar dari dalil) (Al Ghazali, tt: 165).

Ketiga; Penulis mengemukakan ada 5 prinsip penetapan hukum berdasarkan pada isyarat dan kandungan nash, bukan pada teks, yaitu:

(1). Iqtitda' yaitu mengambil hukum bukan berdasarkan lahiriah yang ditunjukkan oleh lafaz nash, namun berdasarkan pada prinsip

Yudisia, Vol. 9, No. 1, Jan-Jun 2018 
bahwa apa yang disampaikan dalam teks itu mengandung kebenaran dari mutakallim, atau jelas sekali yang disampailkan mutakallim bersifat syar' $i$, atau secara logika pasti dapat diterima. Adapun cara yang ditempuh untuk merealisasikan tiga prinsip di atas adalah dengan mentaqdirkan suatu lafaz tertentu. Contoh, sabda Nabi:

$$
\text { لا صيام لمن لم يبيت الصيام من الليل }
$$

Untuk mendapatkan pengertian yang tepat dari hadits tersebut maka dapat ditambahkan kata لاصيام صحيح او كامل

(2). Isyarat yaitu menggunakan makna isyarat dari suatu nash, bukan berdasarkan pada lafaz nash itu sendiri.

Contoh dari isyarat ini adalah istidlal Imam Syafi'i dalam hal najisnya air sedikit yang kena najis walaupun tidak merubah sifat-sifat air tersebut, berdasarkan hadists Nabi;

اذا استيقظ احدكم من نومه فلا يغس يده في الاناء حتى يغسلها ثلاثا فانه لا يدري اين

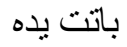

Menurut Imam Syafi'i seandainya bukan karena asumsi adanya najis maka Rasul tidak memerintahkan membasuh tangan.

(3). Memahami illat (alasan) yang terkait dengan sifat yang sesuai.

Contoh dari metode ini adalah ayat ;

و السارق و السارقة فاقطعو ا اديهما

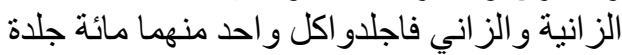

Alasan pemotongan tangan dan hukuman jilid adalah karena mencuri atau berzina dan itu dapat dipahami dari fahwa al kalam.

(4). Memahami kandungan nash berdasarkan pada konteks kalimat dan tujuannya.

Contoh dari metode ini adalah;

$$
\text { فلا تقل لهما اف و لا تنهر هما }
$$

Ayat tersebut memberikan pemahaman yang lebih luas yaitu diharamkan menghujat, membunuh ataupun memukul kedua orang tua.

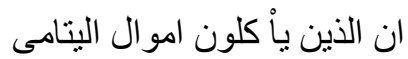

Ayat tersebut memberikan pemahaman yang lebih luas yaitu diharamkan membakar dan juga menghancurkan harta anak yatim. 
(5). Memahami kandungan nash berdasarkan mafhumnya, artinya lafaz yang disebutkan berarti memiliki makna yang khusus dan yang tidak disebutkan berarti tidak termasuk di dalamnya.

Contoh metode mafhum adalah;

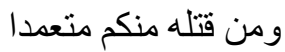

Ayat tersebut memberikan pemahaman bahwa pembunuhan yang dimaksud adalah pembunuhan yang disengaja, bukan karena kelalaian.

Metode ini digunakan oleh Imam Malik, Imam Syafi'i, Imam Asy'ari dan juga kalangan fuqaha. Namun, penulis sependapat dengan Ibnu Syuraih bahwa metode tersebut tidak dapat dijadikan cara beritidla (Al Ghazali, tt: 264).

Keempat; Penulis menetapkan rukun ijtihad ada 3 yaitu;

mujtahid, mujtahad fih (masalah yang dijtihakan), dan ijtihad. Bagi mujtahid disyaratkan dua hal yaitu; (1) Menguasai tata cara berijtihad, dan (2) Orang yang adil dan menjauhi perbuatan dosa. Persyaratan pertama, menguasai tata cara ijtihad, meliputi:

a). Menguasai Al Qur'an. Tidak disyaratkan menguasai seluruh isi Al Qur'an dan hafal ayat-ayatnya, cukuplah dia menguasai ayat-ayat ahkam yang berjumlah lebih kurang 500 ayat.

b). Menguasai Hadits yang terkait dengan ahkam. Tidak disyaratkan baginya menguasai hadits-hadits mauidlah dan hukum-hukum akhirat, dan tidak pula disyaratkan hafal hadits-hadits ahkam tersebut.

c). Menguasai ijma'. Dalam hal ini tidak disyaratkan hafal semua persoalan yang sudah menjadi ijma', namun cukuplah menguasai permasalaha ijma' sesuai dengan kasus yang dihadapi.

d). Menggunakan rasio/akal. Bagi mujtahid supaya menguasai bara'at al ashl dan bara'at al dzimmat.

e). Menguasai kedudukan dalil dan syarat-syaratnya untuk dapat diperoleh hasil sebagai hujjah.

f). Menguasai bahasa dan tata bahasa Arab (nahwu dan sharaf)

g). Menguasai nasikh dan mansukh baik dari ayat Al Qur'an maupun As Sunnah.

h). Menguasai periwayatan hadits dan dapat membedakan antara yang shahih dan yang tidak shahih.

Persyaratan delapan hal di atas berlaku bagi seorang mujtahid mutlak yang menggali semua hukum syar'i. Sedangkan bagi 
mujtahid di bawah tingkatan mujtahid mutlak, seperti mujtahid yang hendak mengqiyaskan suatu persoalan, maka cukuplah dia menguasai persoalan qiyas, dan tidak diharuskan menguasai masalah hadits.

Adapun rukun ijihad yang kedua, mujtahad fih, maka disyaratkan berupa hukum syar'i yang tidak bersifat qath'i. Persoalan yang bersifat aqli dan permasalahan tauhid (kalam) tidak dapat masuk kategori persoalan yang diijtihadkan.

Kebenaran suatu ijtihad masih menjadi masalah khilafiyah di kalangan ulama. Sebagian di antara mereka ada yang berpendapat setiap mujtahid yang melakukan ijtihad pada persoalan dlonniyat adalah benar. Sedangkan sebagian ulama yang lain menyatakan di antara para mujtahid ada yang benar dan ada pula yang salah, karena sesungguhnya kebenaran adalah hanya satu. Penulis sendiri berkeyakinan bahwa semua mujtahid yang melakukan ijtihad adalah benar, karena sesungguhnya Allah tidak menentukan hukum yang muayyan (tertentu) pada setiap persoalan (Al Ghazali, tt: 342). 


\section{E. Simpulan}

Sebuah karya ilmiah tentunya ada nilai lebih dan kurangnya. Kitab Al Mustashfa ini juga mengandung dua hal tersebut. Kelebihan yang ada pada kitab ini adalah:

1). Penulis konsisten dalam menerapkan metode nadlariyat amaliyat yaitu sebuah Metode Syafi'iyah yang menggunakan standar obyektifitas dan empirisitas.

2). Penulis tidak lagi terikat (taqlid) dengan mazhabnya, bahkan ada perbedaan pendapat dengan imam mazhabnya. Sebagai contoh, penulis tidak setuju dengan penggunaan mafhum sebagaimana telah dinyatakan oleh Imam Syafi'i. Sikap independensi penulis ini sesuai dengan Metode Mutakallimin yang senantiasa mencari kebenaran obyektif serta menghindari taqlid.

3). Sistematika pembahasan cukup menarik dan mempermudah pembaca dalam menganalisa ushul fiqh.

Adapun kekurangan dari penulisan kitab ini adalah:

1). Penataan tulisan (lay out) yang kurang elegan, dan membutuhkan perhatian dari pihak-pihak yang berkompeten termasuk percetakan.

2). Cakupan dalam pembahasan ushul fiqh belum secara komprehensip. Sebagai contoh, masalah urf dan sad al dzari'ah belum dibahas dalam kitab tersebut. 


\section{DAFTAR PUSTAKA}

Al Ghazali, Ihya' Ulum al Din, Dar Ihya al Kutub al Araiyah,tth Effendi, Satria, Ushul Fiqh, Jakarta :KencanaPrenada Media Group, 2009

Haroen, Nasroen, Ushul Fiqh Cet-2. Jakarta: PT Logos Wacan Ilmu, 1997

Totok Jumantoro dan Samsul Munir Amin, Kamus Ilmu Ushul Fikih, Jakarta: Amzah, 2005,

Umam, Chaerul, Ushul fiqih 1,Bandung: PustakaSetia, 2008 